\title{
Teleost fish larvae adapt to dietary arachidonic acid supply through modulation of the expression of lipid metabolism and stress response genes
}

\author{
Dulce Alves Martins, ${ }^{1,2 *}$, Filipa Rocha ${ }^{1}$, Gonzalo Martínez-Rodríguez ${ }^{2}$, Gordon Bell ${ }^{3}$, Sofia Morais ${ }^{4}$, \\ Filipa Castanheira ${ }^{1}$, Narcisa Bandarra ${ }^{5}$, Joana Coutinho ${ }^{5}$, Manuel Yúfera ${ }^{2}$ and Luís E. C. Conceição ${ }^{1}$ \\ ${ }^{1}$ Centro de Ciências do Mar do Algarve, Universidade do Algarve, Campus de Gambelas, 8005-139 Faro, Portugal \\ ${ }^{2}$ Instituto de Ciencias Marinas de Andalucía (CSIC), Apartado Oficial E-11510, Puerto Real, Cádiz, Spain \\ ${ }^{3}$ Institute of Aquaculture, University of Stirling, Stirling FK9 4LA, Scotland, UK \\ ${ }^{4}$ IRTA, Centre de Sant Carles de la Rápita, Carretera Poble Nou Km 5·5, 43540 Tarragona, Spain \\ ${ }^{5}$ Instituto Nacional de Recursos Biológicos - Instituto de Investigação das Pescas e do Mar (INRB/IPIMAR), Avenida Brasília, \\ 1449-006 Lisboa, Portugal
}

(Submitted 24 June 2011 - Final revision received 12 October 2011 - Accepted 12 October 2011 - First published online 15 December 2011)

\section{Abstract}

Dietary fatty acid supply can affect stress response in fish during early development. Although knowledge on the mechanisms involved in fatty acid regulation of stress tolerance is scarce, it has often been hypothesised that eicosanoid profiles can influence cortisol production. Genomic cortisol actions are mediated by cytosolic receptors which may respond to cellular fatty acid signalling. An experiment was designed to test the effects of feeding gilthead sea-bream larvae with four microdiets, containing graded arachidonic acid (ARA) levels $(0.4,0.8,1.5$ and $3.0 \%)$, on the expression of genes involved in stress response (steroidogenic acute regulatory protein, glucocorticoid receptor and phosphoenolpyruvate carboxykinase), lipid and, particularly, eicosanoid metabolism (hormone-sensitive lipase, PPAR $\alpha$, phospholipase $\mathrm{A}_{2}$, cyclo-oxygenase-2 and 5-lipoxygenase), as determined by real-time quantitative PCR. Fish fatty acid phenotypes reflected dietary fatty acid profiles. Growth performance, survival after acute stress and similar whole-body basal cortisol levels suggested that sea-bream larvae could tolerate a wide range of dietary ARA levels. Transcription of all genes analysed was significantly reduced at dietary ARA levels above $0 \cdot 4 \%$. Nonetheless, despite practical suppression of phospholipase $\mathrm{A}_{2}$ transcription, higher leukotriene $\mathrm{B}_{4}$ levels were detected in larvae fed $3.0 \%$ ARA, whereas a similar trend was observed regarding $\mathrm{PGE}_{2}$ production. The present study demonstrates that adaptation to a wide range of dietary ARA levels in gilthead sea-bream larvae involves the modulation of the expression of genes related to eicosanoid synthesis, lipid metabolism and stress response. The roles of ARA, other polyunsaturates and eicosanoids as signals in this process are discussed.

\section{Key words: PUFA: Sparus aurata: Gene expression: Stress}

Intensive fish aquaculture can have a negative impact on animal welfare, hence farming practices have been developed with the intention of minimising stress below the threshold of prepathological manifestation, thereby avoiding diseases and mortality ${ }^{(1)}$. Stress resistance has been admitted as an important indicator of a fish's physiological condition and considered as a target for genetic improvement since stress can negatively affect relevant production traits ${ }^{(2,3)}$. The unavailability of essential nutrients, especially during delicate early life stages, may compromise normal development and survival. In fact, high mortalities (up to $99 \%$ in nature) are considered normal for marine teleost larvae. In the face of a stressor, energetic resources must be diverted away from growth and other biological processes into a stress-coping response. Therefore, it is important to provide fish larvae with nutrients that optimise their growth and survival, and that satisfy extra energy requirements inherent to intensive production. Dietary lipid, in particular, strongly influences immunity and response to stress associated with handling and suboptimal environmental conditions ${ }^{(4-6)}$.

Dietary lipids are a major source of energy and provide essential fatty acids and phospholipids, widely acknowledged as critical success factors for larval fish rearing ${ }^{(7,8)}$. In marine fish nutrition, major attention has been given to DHA (22:6n-3) and EPA $(20: 5 n-3)$ due to their predominance in

\footnotetext{
Abbreviations: ARA, arachidonic acid; COX, cyclo-oxygenase; DAH, days after hatch; GR, glucocorticoid receptors; HSL, hormone-sensitive lipase; LA, linoleic acid; LC-PUFA, long-chain PUFA; LNA, linolenic acid; LOX, lipoxygenase; LTB 4 , leukotriene $\mathrm{B}_{4}$; OA, oleic acid; PEPCK, phosphoenolpyruvate carboxykinase; StAR, steroidogenic acute regulatory protein.
}

*Corresponding author: Dr D. Alves Martins, fax +351 289800 069, email dmartins@proyinves.ulpgc.es 
fish tissues, particularly in cell membranes, but the potential of arachidonic acid (ARA; $20: 4 n-6$ ) to affect growth, survival and stress resistance has also been recognised ${ }^{(9,10)}$. The dietary requirement for ARA during early larval development in gilthead sea bream (Sparus aurata) has been linked to survival during the stressful events of metamorphosis, weaning, crowding, grading ${ }^{(11)}$ and other handling procedures ${ }^{(12-14)}$. Various fatty acids and phospholipids have long been demonstrated to present stress resistance conferring properties in fish ${ }^{(15-19)}$, although the mechanisms involved are still somewhat speculative.

Modulation of cellular membrane structure and/or function, through diet-induced changes in phosphoacylglycerol fatty acids, is probably responsible for major dietary outcomes on fish physiology ${ }^{(7,20)}$, including stress-reducing effects ${ }^{(5)}$. The consequences of dietary supplementation in certain longchain PUFA (LC-PUFA) on stress tolerance in fish are often suggested to be mediated by eicosanoids, affecting corticosteroid production ${ }^{(9,13,14,21)}$. Most studies addressing this issue have focused on ARA-derived eicosanoids since these are generally considered the most abundant and bioactive, whereas those produced from EPA tend to be of lower efficacy ${ }^{(22,23)}$. Recent in vitro studies using gilthead sea-bream head kidney cells have clearly demonstrated the participation of cyclo-oxygenase (COX) and lipoxygenase (LOX) metabolites on cortisol release ${ }^{(24,25)}$, as hypothesised in a model proposed for steroidogenesis regulation in mammals ${ }^{(26)}$. The regulation of the steroidogenic acute regulatory protein (StAR), a key rate-limiting enzyme in steroidogenesis, by ARA and its metabolites has still not been examined in fish. In mammalian research, for example, COX-2 inhibition, or 5-LOX- and epoxygenase-derived ARA metabolites have been reported to enhance StAR gene transcription and steroidogenesis ${ }^{(27-29)}$.

Furthermore, fatty acids and eicosanoids serve as ligands for nuclear receptors which may affect the transcription of genes involved in lipid and energy homeostasis, including cholesterol metabolism ${ }^{(30,31)}$ which is central in steroidogenesis. Indeed, PPAR have been reported to modulate genes involved in cholesterol uptake and transport ${ }^{(32)}$, including $\operatorname{StAR}^{(33)}$, hence affecting steroid production in mammals ${ }^{(34)}$. Similar interactions between PPAR and StAR have recently been implicated in Atlantic salmon (Salmo salar) ${ }^{(35)}$.

Cortisol release from the interrenal cells may be affected by the relative abundance of fatty acids through other pathways, such as Ca messenger systems ${ }^{(26)}$. Enhancement of intracellular calcium levels by ARA or its metabolites, including leukotriene $\mathrm{B}_{4}\left(\mathrm{LTB}_{4}\right)^{(36-39)}$, could play an additional role in steroidogenesis regulation.

Within target cells, cortisol signalling entails the activation of glucocorticoid receptors (GR), their translocation into the nucleus and binding to the promoter of glucocorticoid responsive genes, hence modulating their expression ${ }^{(40)}$. In fish, the existence of non-genomic pathways involving membranebound proteins is still unclear ${ }^{(41,42)}$. A study in sea-bream larvae showed that GR mRNA abundance could be affected by dietary lecithin source ${ }^{(43)}$. Also, in vitro studies in fish ${ }^{(44)}$ and mammals ${ }^{(45,46)}$ have shown dose-dependent suppression of GR binding by unsaturated fatty acids, a mechanism possibly mediated in vivo by fatty acid binding proteins ${ }^{(47)}$. Despite the common use of cortisol as a stress indicator, GR are recognised to mediate actual physiological effects of this hormone. Hence, studying the potential of dietary fatty acids to modulate these receptors is likely to provide clues as to how lipid nutrition could affect the stress response in fish larvae.

The objective of the present study was to advance our knowledge on the role of dietary fatty acids in regulating metabolic pathways involved in stress response in fish. Specifically, we have examined potential effects of dietary ARA levels on cortisol production and the expression of genes related to the stress response in gilthead sea-bream larvae. These included StAR, GR, PPAR $\alpha$ and eicosanoid synthesis enzymes. The transcription of hormone-sensitive lipase (HSL), possibly regulated by $\mathrm{GR}^{(48,49)}$, and phosphoenolpyruvate carboxykinase (PEPCK) was also analysed. The production of ARA-derived eicosanoids $\left(\mathrm{PGE}_{2}\right.$ and $\mathrm{LTB}_{4}$ ) was determined, and overall results were examined in light of larval fatty acid phenotypes.

\section{Experimental methods}

\section{Larval rearing}

Animal manipulations were carried out in compliance with the Guidelines of the European Union Council (86/609/EU) and Portuguese legislation for the use of laboratory animals. Protocols were performed under license of Group-1 from the General Directorate of Veterinary (Ministry of Agriculture, Rural Development and Fisheries, Portugal).

Gilthead sea-bream eggs were obtained from INRB/IPIMAR EPPO facility (Olhão, Portugal) and the experiment was conducted at the Centre of Marine Sciences (University of Algarve, Faro, Portugal). The larvae were distributed into twelve cylindro-conical tanks (100 litres), at a density of 100 larvae per litre. This tank system was supplied with constantly aerated seawater $\left(18.4 \pm 0.6^{\circ} \mathrm{C}\right.$, salinity about 35.6 and dissolved oxygen about $6 \mathrm{mg} / \mathrm{l}$ ), kept under a photoperiod of $14 \mathrm{~h}$ light-10 h dark until 16 days after hatch (DAH) and constant lighting conditions from thereon. Tank water renewal was 0.5 times daily initially and increased up to eight times per $\mathrm{d}$ throughout the course of the experiment. During this period, the green water technique was applied to the rearing tanks with the addition of Tetraselmis suecica (clone chuii) and Isochrysis galbana. From $4 \mathrm{DAH}$, the larvae were fed rotifers (Brachionus plicatilis) previously enriched with a commercial product (Easy DHA Selco; INVE Aquaculture), and gradual replacement with the experimental microdiets occurred from 9 to $25 \mathrm{DAH}$, after which the larvae were fed exclusively on the microdiets. However, from $15 \mathrm{DAH}$, the amount of rotifers supplied was nutritionally negligible (about 1 rotifer per $\mathrm{ml}$ ) in order to stimulate larval feeding behaviour. Monitoring of water quality, tank maintenance and removal of mortalities were performed daily.

\section{Experimental diets}

For the experiment, four microdiets were manufactured according to the method of microencapsulation by 
emulsification and internal gelation ${ }^{(50)}$ and presented graded ARA levels ranging from 3.7 to $30.0 \mathrm{~g} / \mathrm{kg}$ feed. These doses were selected in order to vary from a relatively low ARA level commonly found in larval microdiets to a level sufficiently high as to lower the dietary EPA:ARA ratio below 1 . This was expected to highlight potential effects of ARA abundance in the tissues on the expression of genes and other parameters studied. Dietary formulations are presented in Table 1. Sieving allowed the separation of the microdiets into two size classes to be used according to larval size: $80-200 \mu \mathrm{m}$ and $200-400 \mu \mathrm{m}$.

\section{Experimental design and sampling procedures}

The beginning of this experiment was considered to be at 16 DAH, when about $75 \%$ of the larvae were estimated to accept the microdiets, through the microscopic observation of gut content. The photoperiod was then changed to continuous lighting conditions and rotifer supply reduced considerably. The microdiets were tested in triplicate and distributed by automatic feeders (Fishmate; PETMATE) five times per $\mathrm{d}$ from 9 to $16 \mathrm{DAH}$, and eight times per d (every $3 \mathrm{~h}$ ) from 16 until $34 \mathrm{DAH}$.

At the end of the experiment, thirty larvae per tank were subjected to an acute stress consisting of 1 min gentle stirring, in a 1 litre beaker, and left to recover for $24 \mathrm{~h}$ at the end of which mortalities were recorded and live larvae sampled for whole-body cortisol determination. Cortisol levels were determined under basal conditions and at $24 \mathrm{~h}$ post-stress only, due to the shortage of larvae at the end of the experiment and the large number of fish required for other biochemical analyses. The $24 \mathrm{~h}$ period was selected in order to evaluate also stress resistance (survival) $1 \mathrm{~d}$ after acute stress.

Initial average dry weight (16DAH) was determined from pooled samples (200 larvae per tank), which were stored at $-20^{\circ} \mathrm{C}$ until measurements could be conducted. At the final sampling, fifty larvae per tank were collected for individual dry-weight assessment, and about 100 per tank were stored at $-80^{\circ} \mathrm{C}$ for lipid and fatty acid composition analysis. Whole-body cortisol concentration was assessed, before ( $n$ 15) and $24 \mathrm{~h}$ after stress ( $n$ 15), in pooled larvae samples which were kept at $-80^{\circ} \mathrm{C}$ until analyses could be conducted. Furthermore, fifty larvae per tank were sampled for wholebody eicosanoid determination and stored in Hanks' balanced salt solution (Sigma), containing 15\% ethanol (v/v) and 5\% formic acid $(2 \mathrm{M})$, at $-20^{\circ} \mathrm{C}$. Finally, for gene expression analysis, ten larvae per tank were preserved in RNAlater at $4^{\circ} \mathrm{C}$ for $24 \mathrm{~h}$ and then at $-20^{\circ} \mathrm{C}$. All larvae sampled were previously anaesthetised with an overdose of 2-phenoxyethanol and washed with distilled water before storage or measurements, with the exception of those intended for gene expression analysis, which were stored directly in RNAlater.

\section{Analytical methods}

The microdiets were analysed for proximate composition according to the following procedures: DM determined gravimetrically by drying in an oven at $105^{\circ} \mathrm{C}$ for $24 \mathrm{~h}$; crude ash by
Table 1. Formulation and proximate composition of the experimental microencapsulated diets, prepared by internal gelation, for gilthead seabream larvae

\begin{tabular}{|c|c|c|c|c|}
\hline & \multicolumn{4}{|c|}{ Diets } \\
\hline & ARA0. 4 & ARA0.8 & ARA1.5 & ARA3.0 \\
\hline \multicolumn{5}{|l|}{ Ingredients (g/kg) } \\
\hline Fishmeal $^{*}$ & $50 \cdot 0$ & $50 \cdot 0$ & $50 \cdot 0$ & $50 \cdot 0$ \\
\hline Fish hydrolysate $\dagger$ & $100 \cdot 0$ & $100 \cdot 0$ & $100 \cdot 0$ & $100 \cdot 0$ \\
\hline Cuttlefish meal¥ & $420 \cdot 0$ & $420 \cdot 0$ & $420 \cdot 0$ & $420 \cdot 0$ \\
\hline Casein§ & $50 \cdot 0$ & 50.0 & $50 \cdot 0$ & $50 \cdot 0$ \\
\hline Sodium alginate\| & $70 \cdot 0$ & $70 \cdot 0$ & $70 \cdot 0$ & $70 \cdot 0$ \\
\hline Dextrin & $13 \cdot 0$ & 9.0 & 7.0 & 4.0 \\
\hline Soyabean lecithin ${ }^{\star \star}$ & $50 \cdot 0$ & $50 \cdot 0$ & $50 \cdot 0$ & $50 \cdot 0$ \\
\hline Linseed oilt† & $35 \cdot 0$ & $30 \cdot 0$ & $30 \cdot 0$ & - \\
\hline Sunflower oilł‡ & $34 \cdot 0$ & $30 \cdot 0$ & $10 \cdot 0$ & - \\
\hline Olive oil§§ & $20 \cdot 0$ & $20 \cdot 0$ & $20 \cdot 0$ & $20 \cdot 0$ \\
\hline ARASCO\|\|\| & $7 \cdot 0$ & $21 \cdot 0$ & 44.0 & 88.0 \\
\hline DHASCO॥ १ & $40 \cdot 0$ & $40 \cdot 0$ & $40 \cdot 0$ & $40 \cdot 0$ \\
\hline Incromega ${ }^{\star \star *}$ & $31 \cdot 0$ & $30 \cdot 0$ & 29.0 & 28.0 \\
\hline Vitamin premix $† \dagger \dagger$ & $20 \cdot 0$ & $20 \cdot 0$ & $20 \cdot 0$ & $20 \cdot 0$ \\
\hline Vitamin C $\neq \ddagger \ddagger$ & $30 \cdot 0$ & $30 \cdot 0$ & $30 \cdot 0$ & $30 \cdot 0$ \\
\hline Vitamin E§§§ & $10 \cdot 0$ & $10 \cdot 0$ & $10 \cdot 0$ & $10 \cdot 0$ \\
\hline Mineral premix|||||| & $20 \cdot 0$ & $20 \cdot 0$ & $20 \cdot 0$ & $20 \cdot 0$ \\
\hline \multicolumn{5}{|l|}{ Proximate composition } \\
\hline DM (\%) & $97 \cdot 4$ & $96 \cdot 8$ & $96 \cdot 9$ & $97 \cdot 1$ \\
\hline Protein (\% DM) & $58 \cdot 0$ & 59.5 & 59.5 & 57.9 \\
\hline Lipid (\% DM) & $27 \cdot 3$ & $25 \cdot 0$ & $25 \cdot 4$ & $27 \cdot 3$ \\
\hline Ash (\% DM) & $3 \cdot 8$ & 3.5 & 4.0 & $3 \cdot 7$ \\
\hline Carbohydrates (\% DM) ๆ १ & $10 \cdot 9$ & 11.9 & $11 \cdot 1$ & 11.0 \\
\hline Energy (kJ/g DM) & 25.4 & $25 \cdot 1$ & $25 \cdot 2$ & $25 \cdot 8$ \\
\hline
\end{tabular}

*AgloNorse Microfeed (Norsildmel Innovation AS)

† CPSP-90 (Sopropeche).

‡ Squid Powder 0278 (Rieber \& Søn ASA).

$\S$ VWR International.

॥ MP Biomedicals 154724

I Commercial grade type I (MP Biomedicals)

${ }_{* \star}^{*}$ Lecithin Soy Refined (MP Biomedicals).

††Commercial linseed oil (Biolasi Productos Naturales, S.L.).

¥¥Commercial sunflower oil (Ibarrasol, Aceites Ybarra S.A.).

$\S \S$ Commercial olive oil (Hacendado, Sovena Iberica de Aceites S.A.).

III Vegetable oil from fungi, approximately $40 \%$ ARA, Martek life enriched TM (Martek Biosciences Corporation).

9 1 Vegetable oil from microalgae, approximately $40 \%$ DHA, Martek life enriched TM (Martek Biosciences Corporation).

${ }^{* * *}$ Incromega TG7010 SR (Croda Europe Limited).

†† Vitamin premix supplied the following (per $\mathrm{kg}$ of diet): retinol-cholecalciferol 500:100, $1000 \mathrm{mg}$; cholecalciferol 500, $40 \mathrm{mg} ; \alpha$-tocopherol acetate, $3000 \mathrm{mg}$; menadione $23 \%$, $220 \mathrm{mg}$; thiamin $\mathrm{HCl}, 50 \mathrm{mg}$; riboflavin $80,250 \mathrm{mg}$; D-calcium pantothenic acid, $1100 \mathrm{mg}$; nicotinamide, $500 \mathrm{mg}$; pyridoxine, $150 \mathrm{mg}$; pteroylglutamic acid, $50 \mathrm{mg}$; cyanocobalamin 0.1, $500 \mathrm{mg}$; biotin $20,38 \mathrm{mg}$; ascorbic acid polyphosphate $35 \%, 57.2 \mathrm{~g}$; choline chloride $60 \%, 100 \mathrm{~g}$; myo-inositol, $15 \mathrm{~g}$; antioxidants, $1.25 \%$.

㧊 Sodium, calcium ascorbyl-2-phosphate, Rovimix STAY-C 35 (DSM Nutritional Products, Inc.)

$\S \S \S \mathrm{DL}-\alpha-$-Tocopherol acetate (MP Biomedicals 100555).

|IIII Mineral premix supplied the following (per $\mathrm{kg}$ of diet): monocalcium phosphate, $35.2 \%$; calcium carbonate, $11.5 \%$; NaCl, $20 \%$; potassium chloride, $26 \%$; copper sulphate, $0.024 \%$; magnesium sulphate, $5 \%$; ferrous sulphate, $0.6 \%$; manganous sulphate, $0.81 \%$; zinc sulphate, $0.17 \%$; potassium iodide, $0.0031 \%$; sodium selenite, $0.6 \%$.

१ १ ๆ Carbohydrates $=100-$ (protein + lipid + ash).

incineration in a muffle furnace at $500^{\circ} \mathrm{C}$ for $12 \mathrm{~h}$; crude protein $(\mathrm{N} \times 6.25)$ assessed by a $\mathrm{N}$ determinator (LECO, FP-528); total lipid extracted with petroleum diethyl ether (Soxhlet $40-60^{\circ} \mathrm{C}$ ); gross energy in an adiabatic bomb calorimeter (IKA C2000). For fatty acid composition analyses of the microdiets and larvae, acid-catalysed transesterification ${ }^{(51)}$ was performed, to produce fatty acid methyl esters which were measured and quantified by GC in a Varian Star 3800 
CP equipped with an auto-sampler and fitted with a flame ionisation detector at $250^{\circ} \mathrm{C}$. The separation was performed in a polyethylene glycol capillary column DB-WAX $30 \mathrm{~m}$ in length, $0.25 \mathrm{~mm}$ in inner diameter and $0.25 \mathrm{~mm}$ in film thickness from J\&W Scientific. The column was subjected to a temperature programme starting at $180^{\circ} \mathrm{C}$ for $5 \mathrm{~min}$, increasing by $4^{\circ} \mathrm{C} / \mathrm{min}$ for $10 \mathrm{~min}$ and held at $220^{\circ} \mathrm{C}$ for $25 \mathrm{~min}$. The injector (split ratio 100:1) and detector temperatures were kept constant at $250^{\circ} \mathrm{C}$ during the $40 \mathrm{~min}$ analysis. Fatty acid peaks were identified by directly comparing retention times with those of a known standard ('PUFA 3'; Sigma-Aldrich ${ }^{\circledR}$ ) and quantified by means of the response factor to an internal standard (21:0) which was used at $5 \mathrm{ml} / \mathrm{mg}$ sample.

Survival at the end of the experiment and at $24 \mathrm{~h}$ post-stress was determined by direct counting of individuals, relative to the initially stocked number of larvae, and excluding the 200 individuals sampled at $16 \mathrm{DAH}$. Individual determination of whole-body dry weight was performed in a Sartorius M5P balance (0.001 mg precision; Sartorius micro) after freezedrying the samples for $24 \mathrm{~h}$ in a Savant SS31 (Savant Instruments, Inc.).

Whole-body cortisol was determined in pooled larvae samples of about 150-300 mg per tank (wet weight), according to methodology which has been described previously ${ }^{(43)}$, and using a commercial cortisol ELISA kit (Neogen Corporation).

For the determination of whole-body eicosanoid concentration, samples were homogenised in the storage solution and centrifuged to remove debris. The supernatants were extracted using octadecyl silyl $\left(\mathrm{C}_{18}\right)$ 'Sep-Pak' cartridges (Millipore), as described in detail by Bell et al. ${ }^{(52)}$. The extracts were dried under $\mathrm{N}_{2}$, redissolved in $1 \mathrm{ml}$ of methanol and stored in glass vials at $-20^{\circ} \mathrm{C}$ until immunoassay analysis. Upon sample preparation for analysis, $500 \mu \mathrm{l}$ of the methanol extracts were dried under $\mathrm{N}_{2}$, redissolved in $2 \mathrm{ml}$ enzyme immunoassay (EIA) buffer and loaded onto the plate contained in the assay kit. Eicosanoids were quantified using enzyme immunoassay kits, namely $\mathrm{PGE}_{2}$ EIA kit (Cayman, ref. 514010) and $\mathrm{LTB}_{4}$ EIA kit (Cayman, ref. 520111), according to the manufacturer's instructions.

Total RNA from individual fish larvae (average weight $1.5 \mathrm{mg}$ ) was extracted using the QIAGEN RNeasy ${ }^{\circledR}$ Plus Mini Kit designed to purify RNA from small amounts of animal tissues (maximum $30 \mathrm{mg}$ ), allowing yields of up to $100 \mu \mathrm{g}$ total RNA. Total body tissue was disrupted and homogenised using a rotor-stator homogeniser Ultra Turrax T8 $\left(\right.$ IKA $^{\circledR}{ }_{-}$ Werke) and RTL plus buffer. The lysate was passed through a genomic DNA eliminator spin column to remove all genomic DNA contamination. The sample was transferred into an RNeasy spin column where total RNA bonded to a membrane and contaminants were washed away. Purified RNA was then eluted with $30 \mu \mathrm{l}$ of RNase-free water. The quality and quantity of the RNA were assessed using the Bioanalyzer 2100 (Agilent Biosystem) and the RNA 6000 Nano kit, accurate to a qualitative range of 5-500 ng/ $\mu \mathrm{l}$. A nanochip carried up to twelve RNA samples of $1 \mu \mathrm{l}$ each. Through electrophoresis analysis of RNA with nanochips, two peaks were detected in wellpreserved samples (RNA fragments $18 \mathrm{~S}$ and 28S). After detection, the ratio of the fragment areas and the RNA integrity number were calculated. RNA was quantified spectrophotometrically at $260 \mathrm{~nm}$ using the Eppendorf Biophotometer Plus and plastic Eppendorf UVettes ${ }^{\circledR}$ RNase free. The analysis was performed with $5 \mu \mathrm{l}$ per sample, diluted with $50 \mu \mathrm{l}$ of DEPC water and the correction factor automatically calculated. Complementary DNA were synthesised from $500 \mathrm{ng}$ of total RNA using the qScript-cDNA synthesis kit (Quanta Bioscience ${ }^{\mathrm{TM}}$ ), according to the manufacturer's instructions, in a Mastercycler ${ }^{\circledR}$ VapoProtec (Eppendorf, ProS).

Gene expression was analysed by real-time quantitative PCR using the Mastercycler ${ }^{\circledR}$ ep Realplex ${ }^{2}$ S system (Eppendorf) and the procedure provided by the PerfeCTa SYBR Green kit (Quanta). Sea-bream specific primers were used, with $\beta$-actin as the normalisation gene, in a final volume of $20 \mu \mathrm{l}$ per reaction well, using $12 \mathrm{ng}$ of total RNA reverse transcribed to complementary DNA. The amount of complementary DNA per reaction was established after $a$ priori optimisation tests, considering the efficiency of the amplification process and the regression fit to six serial 10-fold dilutions of complementary DNA. Moreover, each primer-pair annealing temperature and concentration were established in advance using the temperature gradient function of the thermocycler. Each gene sample was analysed in triplicate. The PCR conditions were as follows: $95^{\circ} \mathrm{C}$ for $5 \mathrm{~min}$ followed by forty cycles of $95^{\circ} \mathrm{C}$ for $15 \mathrm{~s}$ and $60^{\circ} \mathrm{C}$ for $30 \mathrm{~s}$, and a final denaturing step from $60^{\circ}$ to $95^{\circ} \mathrm{C}$ during $20 \mathrm{~min}$ to check for primerdimers and spurious amplification products. The $\Delta \Delta C_{\mathrm{t}}$ $\operatorname{method}^{(53)}$ was used to determine the relative mRNA expression levels. For gilthead sea-bream specific primer design, nucleotide and EST GenBank databases were searched for the following genes: $P L A_{2}, C O X-2,5-L O X$, StAR, GR, PPAR, PEPCK and HSL. Oligonucleotides were designed using the Primer3 program, and ordered HPLC-purified. Primer sequences and accession numbers for the mRNA analysed are described in Table 2.

\section{Statistical analysis}

Larval growth expressed as relative growth rate was determined at the end of the experiment for all treatment groups, according to the following equation ${ }^{(54)}$ : relative growth rate $=\left(e^{g}-1\right) \times 100$, where $g=((\ln$ final weight $-\ln$ initial weight)/time)). A one-way ANOVA was used, with dietary treatment as the independent variable, for the statistical analysis of growth performance, whole-body fatty acid composition, eicosanoid and gene expression data. For the data not presenting variance homogeneity and normal distribution, the Kruskal-Wallis and Dunnett tests were performed. Cortisol data were analysed by a $2 \times 2$ mixed-design ANOVA to assess the effect of diet (between-subject variable) and sampling time (within-subject variable, i.e. differences between the basal values and levels detected $24 \mathrm{~h}$ poststress). Differences were considered significant when $P<0 \cdot 05$. Tukey's honestly significant difference (HSD) multiple mean comparison test was used to identify differences between the means. The relationships between fatty acid concentrations in the diet and in fish can differ among the fatty acids. Hence, Pearson's correlation coefficients and 
Table 2. Sequences of forward and reverse primers $\left(5^{\prime}-3^{\prime}\right)$ for real-time quantitative-PCR of sea-bream genes and amplification product size

\begin{tabular}{|c|c|c|c|c|}
\hline Primer & Forward & Reverse & Product size $(\mathrm{bp})$ & Accession no. \\
\hline$\beta$-Actin & TCTTCCAGCCATCCTTCCTCG & TGTTGGCATACAGGTCCTTACGG & 108 & X89920 \\
\hline StAR & ACGCAGGTGGACTTTGCCAAC & TGAGTGCACGGTGCCAAAGC & 115 & EF640987 \\
\hline GR & GATGACCACCCTCAACAGGT & TTAGGAAGAGCCAGGAGCAC & 134 & DQ486890 \\
\hline $\operatorname{PPAR} \alpha$ & ACCGCAACAAGTGCCAGTA & TTCTCCACCACCTTTCGTTC & 133 & AY590299 \\
\hline $\mathrm{PLA}_{2}$ & CCAGACCATCTTCACCATCC & CACCCAATCCACAGGAGTTC & 114 & AF427868 \\
\hline coX-2 & CGTCTGCAATAACGTGAAGG & CCTGAGTGGGACGTGCTC & 105 & AM296029 \\
\hline 5-LOX & CCTGGCAGATGTGAACTTGA & CGTTCTCCTGATACTGGCTGA & 100 & FP334124 \\
\hline HSL & CGGCTTTGCTTCAGTTTACC & АCССTTCTGGATGATGTGGA & 115 & EU254478 \\
\hline PEPCK & AGAGCCATCAACCCTGAGAA & СТСССАССАСАСТССТССАТ & 144 & AF427868 \\
\hline
\end{tabular}

StAR, steroidogenic acute regulatory protein; GR, glucocorticoid receptor; PLA, phospholipase $\mathrm{A}_{2}$; COX-2, cyclo-oxygenase-2; 5-LOX, 5-lipoxygenase; HSL, hormonesensitive lipase; PEPCK, phosphoenolpyruvate carboxykinase.

differences ( $\Delta$ values) between the percentages of selected fatty acids in larval lipids and in dietary lipids were calculated (\% total fatty acids). Pearson's coefficients were also used to explore correlations between cortisol levels and the fatty acid content of the larvae. All statistical tests were conducted with the software package SPSS ${ }^{\circledR} 16.0$ for Windows ${ }^{\circledR}$.

\section{Results}

The proximate composition of the microdiets showed crude protein levels of 58-60\%, crude lipid content between 25 and $27 \%$, and gross energy about $25 \mathrm{~kJ} / \mathrm{g}$ DM (Table 1). Dietary fatty acid composition is presented in Table 3 . Total fatty acid content analysis showed values between 171 and $182 \mathrm{mg} / \mathrm{g}$ diet. Saturates represented $3 \cdot 4-4 \cdot 0 \%$ of the diet, whereas MUFA were about 4.3-4.5\%, mainly oleic acid (18: 1n-9). PUFA content ranged from $9 \cdot 3$ to $10 \cdot 2 \%$. Among polyunsaturates, ARA increased from 0.4 (ARA0.4) to $3.0 \%$ (ARA3.0), whereas linoleic (LA; $18: 2 n-6$ ) and linolenic (LNA; 18:3n-3) acid concentrations decreased with ARA addition. However, EPA and DHA levels were relatively constant between the dietary treatments. Thus, dietary EPA:ARA and DHA:ARA ratios were lowered with increasing dietary ARA inclusion, whereas the DHA:EPA ratio was maintained practically identical between the diets.

Sea-bream initial dry weight was 71.3 (SD 10.6) $\mu \mathrm{g} /$ larva and, despite slightly lower relative growth rates in the midrange treatments at the end of the experiment, no significant differences were observed in growth parameters or survival between the dietary groups (Table 4). Overall, relative growth rate values were approximately 3.6-6.0\% per d, whereas survival was determined between 4.5 and $5.8 \%$. At $24 \mathrm{~h}$ after acute stress, this parameter varied between 84 and $90 \%$ without statistically significant differences between the experimental groups.

Whole-body fatty acid composition reflected dietary profiles, particularly regarding ARA, which increased from $4 \cdot 2 \%$ total fatty acids in the ARA0.4 groups to $11.6 \%$ in ARA3.0 fed larvae (Table 5). Pearson's correlation coefficient for ARA was 0.99 and $\Delta$ values indicated its preferential retention up to $1.5 \%$ dietary content, whereas at the highest dietary concentration tested, $\Delta$ values pointed to its preferential metabolism (Table 6). The DHA content of the sea bream was high $(26 \cdot 8-28.6 \%)$ and $\Delta$ values suggested strong preferential deposition of this fatty acid in fish tissues. On the other hand, despite relatively similar EPA concentrations among the experimental microdiets, larval levels were significantly reduced in the groups fed the ARA1.5 and ARA3. 0 diets. The relationship between larval contents in ARA and EPA was also analysed and Pearson's correlation coefficient (-0.997) indicated a strong negative correlation between the two fatty acids in the tissues (Fig. 1). Furthermore, unlike ARA or DHA, EPA appeared to be preferentially metabolised in all experimental groups, and more so as ARA levels increased in the larvae, as suggested by $\Delta$ values. Regarding the EPA:ARA and DHA:ARA ratios, a significant decrease was noted as ARA deposition increased in the larvae. In particular, the EPA:ARA ratio was only above 1.0 in the group supplied with the lowest ARA levels. The DHA:EPA ratio was highest in the ARA3.0-fed groups. Other polyunsaturates, LA and LNA, decreased significantly, reflecting dietary differences, and seemed to be preferentially metabolised by the larvae as well as oleic acid. No statistically significant differences regarding SFA and MUFA were identified between the

Table 3. Total fatty acid content (mg/g diet DM) and fatty acid composition $(\mathrm{g} / 100 \mathrm{~g}$ diet $\mathrm{DM})$ of the experimental diets

\begin{tabular}{|c|c|c|c|c|}
\hline & \multicolumn{4}{|c|}{ Diets } \\
\hline & ARA0.4 & ARA0.8 & ARA1.5 & ARA3.0 \\
\hline Total FAME & $182 \cdot 2$ & $171 \cdot 7$ & $171 \cdot 3$ & $179 \cdot 3$ \\
\hline \multicolumn{5}{|l|}{ Fatty acid } \\
\hline $16: 0$ & $2 \cdot 2$ & $2 \cdot 0$ & $2 \cdot 1$ & $2 \cdot 4$ \\
\hline $18: 0$ & 0.6 & 0.6 & 0.7 & 0.9 \\
\hline SFA & 3.5 & 3.4 & 3.5 & 4.0 \\
\hline $16: 1 n-7$ & 0.1 & 0.1 & 0.1 & 0.1 \\
\hline $18: 1^{\star}$ & 4.2 & 3.9 & 4.0 & 4.0 \\
\hline $20: 1 n-9$ & 0.2 & 0.2 & 0.2 & 0.2 \\
\hline MUFA & 4.5 & 4.3 & 4.3 & 4.3 \\
\hline $18: 2 n-6$ & 3.4 & $2 \cdot 8$ & 1.9 & 1.5 \\
\hline $20: 4 n-6$ & 0.4 & 0.8 & 1.5 & $3 \cdot 0$ \\
\hline$n-6$ PUFA & 3.8 & 3.6 & 3.6 & 4.7 \\
\hline $18: 3 n-3$ & 1.4 & $1 \cdot 1$ & $1 \cdot 1$ & 0.1 \\
\hline $20: 5 n-3$ & 2.0 & 1.9 & 1.8 & 1.8 \\
\hline $22: 6 n-3$ & $2 \cdot 7$ & $2 \cdot 6$ & $2 \cdot 6$ & $2 \cdot 8$ \\
\hline$n-3$ PUFA & $6 \cdot 3$ & 5.9 & $5 \cdot 7$ & 4.8 \\
\hline PUFA & $10 \cdot 2$ & 9.5 & $9 \cdot 3$ & 9.6 \\
\hline DHA:EPA & 1.3 & 1.4 & 1.4 & 1.5 \\
\hline EPA:ARA & $5 \cdot 4$ & 2.5 & 1.2 & 0.6 \\
\hline DHA:ARA & $7 \cdot 3$ & 3.5 & 1.7 & 0.9 \\
\hline
\end{tabular}

ARA, arachidonic acid; FAME, fatty acid methyl esters.

${ }^{*}$ Includes $18: 1 n-7$ and 18:1n-9. 
Table 4. Growth performance ${ }^{\star}$ and survival at $24 \mathrm{~h}$ after stress of sea-bream larvae fed the experimental diets containing graded arachidonic acid (ARA) levels

(Mean values and standard deviations)

\begin{tabular}{|c|c|c|c|c|c|c|c|c|}
\hline & \multicolumn{2}{|c|}{ ARA0.4 } & \multicolumn{2}{|c|}{ ARA0.8 } & \multicolumn{2}{|c|}{ ARA1.5 } & \multicolumn{2}{|c|}{ ARA3.0 } \\
\hline & Mean & SD & Mean & SD & Mean & SD & Mean & SD \\
\hline Dry weight ( $\mu \mathrm{g} /$ larva) & $186 \cdot 8$ & 39.3 & $160 \cdot 8$ & $5 \cdot 8$ & $159 \cdot 2$ & 9.6 & $196 \cdot 4$ & $62 \cdot 6$ \\
\hline RGR (\%/d, 16-34 DAH) & $5 \cdot 8$ & 1.7 & $5 \cdot 0$ & 0.0 & 3.6 & 1.0 & $6 \cdot 0$ & 1.7 \\
\hline Survival (\%, 16-34 DAH) & $4 \cdot 8$ & 0.5 & $5 \cdot 8$ & 1.4 & $5 \cdot 6$ & $1 \cdot 0$ & 4.5 & 1.7 \\
\hline Survival at $24 \mathrm{~h}(\%)$ & $86 \cdot 3$ & 3.9 & 89.8 & $6 \cdot 3$ & 89.4 & $15 \cdot 3$ & 83.7 & 8.5 \\
\hline
\end{tabular}

RGR, relative growth rate.

*Initial dry weight, 71.3 (SD 10.6) $\mu \mathrm{g} / \mathrm{larva}$.

groups. Finally, palmitic (16:0) and stearic acids (18:0) were preferentially retained in the larval tissues in all experimental groups and their respective Pearson's correlation coefficients were relatively low.

Whole-body basal cortisol levels (Fig. 2) ranged between 12 and $18 \mathrm{ng} / \mathrm{g}$ larvae wet weight, and levels at $24 \mathrm{~h}$ post-stress were between 20 and $30 \mathrm{ng} / \mathrm{g}$. No statistical interaction was found between diet and sampling time $(P=0 \cdot 70)$. Overall, cortisol values did not differ between the experimental groups $(P=0 \cdot 12)$ but significantly higher levels were found at $24 \mathrm{~h}$ post-stress than before stress $(P=0 \cdot 005)$.

Whole-body $\mathrm{PGE}_{2}$ measurements did not show significant differences between the treatments $(P=0 \cdot 21)$, whereas the highest $\mathrm{LTB}_{4}$ levels were determined in sea-bream larvae fed the ARA3.0 diet ( $P=0 \cdot 04$; Fig. 3).
All genes studied showed significant differences in expression among the dietary treatments (Fig. 4). Above the lowest dietary ARA level tested ( $0 \cdot 4 \%)$, the transcription of the eight analysed genes was significantly depressed. In particular, a drastically reduced expression of PLA 2 was observed, whereas other enzymes involved in eicosanoid synthesis (5-LOX and COX-2) showed decreased mRNA levels to only about half in the groups fed $0.8 \%$ ARA and above. PPAR $\alpha$ mRNA abundance was also highest in the lowest ARA-fed groups. The StAR gene, encoding for the rate-limiting enzyme in steroidogenesis, presented a similar trend. On the other hand, GR gene expression appeared to be gradually reduced as dietary ARA supply increased. HSL transcript levels were only slightly higher in ARA0.4-fed larvae when compared with the other groups, while PEPCK gene

Table 5. Whole-body total fatty acid content ( $\mathrm{mg} / \mathrm{g}$ sample) and profile ( $\mathrm{g} / 100 \mathrm{~g}$ total fatty acids) of sea-bream larvae fed diets containing graded arachidonic acid (ARA) levels

(Mean values and standard deviations)

\begin{tabular}{|c|c|c|c|c|c|c|c|c|}
\hline & \multicolumn{2}{|c|}{ ARA0.4 } & \multicolumn{2}{|c|}{ ARA0.8 } & \multicolumn{2}{|c|}{ ARA1.5 } & \multicolumn{2}{|c|}{ ARA3.0 } \\
\hline & Mean & SD & Mean & SD & Mean & SD & Mean & SD \\
\hline Total FAME & $71 \cdot 1$ & $1 \cdot 3$ & $70 \cdot 3$ & $12 \cdot 8$ & $71 \cdot 1$ & $2 \cdot 0$ & $65 \cdot 3$ & $2 \cdot 0$ \\
\hline \multicolumn{9}{|l|}{ Fatty acid } \\
\hline $14: 0$ & 0.9 & 0.0 & 0.9 & 0.1 & 0.8 & 0.0 & 0.8 & 0.1 \\
\hline $16: 0$ & $17 \cdot 8$ & 0.9 & $17 \cdot 0$ & 1.4 & $17 \cdot 4$ & 0.4 & $17 \cdot 4$ & 0.4 \\
\hline $18: 0$ & $10 \cdot 1$ & 0.3 & $9 \cdot 6$ & 0.4 & $10 \cdot 1$ & 0.2 & $10 \cdot 4$ & 0.5 \\
\hline SFA & $30 \cdot 1$ & $1 \cdot 0$ & $29 \cdot 3$ & 1.5 & 29.9 & 0.5 & $30 \cdot 2$ & 0.9 \\
\hline $16: 1 n-9$ & $1 \cdot 0$ & 0.3 & 1.5 & 0.6 & $1 \cdot 1$ & 0.3 & $1 \cdot 1$ & 0.4 \\
\hline $18: 1 n-9$ & $13 \cdot 3$ & 0.1 & $13 \cdot 4$ & 0.4 & $13 \cdot 2$ & 0.1 & $12 \cdot 7$ & 0.3 \\
\hline $20: 1 n-9$ & 0.8 & 0.0 & 0.8 & 0.0 & 0.8 & 0.0 & 0.8 & 0.0 \\
\hline MUFA & $17 \cdot 1$ & 0.5 & $18 \cdot 3$ & $1 \cdot 8$ & $17 \cdot 0$ & 0.7 & $16 \cdot 5$ & $1 \cdot 1$ \\
\hline $18: 2 n-6$ & $7 \cdot 5^{a}$ & 0.0 & $6 \cdot 3^{b}$ & 0.3 & $4 \cdot 6^{c}$ & 0.2 & $3.4^{d}$ & 0.2 \\
\hline $20: 4 n-6$ & $4 \cdot 2^{a}$ & 0.2 & $5 \cdot 5^{a}$ & 0.8 & $8 \cdot 7^{b}$ & 0.7 & $11 \cdot 6^{c}$ & $1 \cdot 2$ \\
\hline$n-6$ PUFA & $12 \cdot 4^{a}$ & 0.1 & $12 \cdot 9^{\mathrm{a}}$ & $1 \cdot 2$ & $14 \cdot 4^{a, b}$ & 0.6 & $16 \cdot 2^{b}$ & 0.7 \\
\hline $18: 3 n-3$ & $1 \cdot 3^{a}$ & 0.0 & $1 \cdot 1^{a, b}$ & 0.0 & $1 \cdot 0^{b}$ & 0.1 & $0 \cdot 2^{c}$ & 0.1 \\
\hline $18: 4 n-3$ & $0 \cdot 3^{a}$ & 0.1 & $0.3^{a}$ & 0.0 & $0.4^{a, b}$ & 0.0 & $0.5^{\mathrm{b}}$ & 0.1 \\
\hline $20: 4 n-3$ & 0.4 & 0.1 & 0.4 & 0.1 & 0.4 & 0.1 & 0.4 & 0.1 \\
\hline $20: 5 n-3$ & $5 \cdot 7^{\mathrm{a}}$ & 0.1 & $5 \cdot 2^{\mathrm{a}}$ & 0.2 & $4 \cdot 2^{b}$ & 0.1 & $3 \cdot 4^{\mathrm{b}}$ & 0.4 \\
\hline $22: 6 n-3$ & $28 \cdot 6$ & $1 \cdot 0$ & $27 \cdot 1$ & 0.9 & $27 \cdot 2$ & 0.4 & $26 \cdot 8$ & 0.9 \\
\hline n-3 PUFA & $37 \cdot 7^{\mathrm{a}}$ & 0.8 & $35 \cdot 6^{\mathrm{b}}$ & 0.5 & $34 \cdot 7^{\mathrm{b}}$ & 0.4 & $32 \cdot 7^{c}$ & 0.3 \\
\hline PUFA & $50 \cdot 4$ & 0.7 & $48 \cdot 7$ & $1 \cdot 7$ & $49 \cdot 4$ & $1 \cdot 0$ & $49 \cdot 2$ & $1 \cdot 0$ \\
\hline$n-3$ PUFA: $n-6$ PUFA & $3 \cdot 0^{\mathrm{a}}$ & 0.1 & $2 \cdot 8^{a, b}$ & 0.2 & $2 \cdot 4^{\mathrm{b}}$ & 0.1 & $2 \cdot 0^{\mathrm{C}}$ & 0.1 \\
\hline DHA:EPA & $5 \cdot 0^{\mathrm{a}}$ & 0.1 & $5 \cdot 2^{a}$ & 0.2 & $6 \cdot 5^{a, b}$ & 0.0 & $7 \cdot 9^{b}$ & 0.1 \\
\hline EPA:ARA & $1.4^{\mathrm{a}}$ & 0.2 & $1 \cdot 0^{b}$ & 0.4 & $0.5^{\mathrm{c}}$ & 0.1 & $0.3^{c}$ & $1 \cdot 2$ \\
\hline DHA:ARA & $6 \cdot 7^{\mathrm{a}}$ & 0.1 & $5 \cdot 0^{b}$ & 0.6 & $3 \cdot 1^{c}$ & 0.2 & $2 \cdot 3^{c}$ & 0.2 \\
\hline
\end{tabular}

FAME, fatty acid methyl esters.

$\mathrm{a}, \mathrm{b}, \mathrm{c}, \mathrm{d}$ Mean values within a row with unlike superscript letters were statistically significantly different $(P<0.05 ;$ ANOVA). 
Table 6. Pearson's correlation coefficients $(r)$ and slopes of linear regressions between selected fatty acid content in the microdiets and larvae, and differences $(\Delta)$ between fatty acid levels in larvae and in the corresponding experimental diets (\% total fatty acids) ${ }^{*}$

\begin{tabular}{lcccccr}
\hline Fatty acid & $r$ & Slope & $\Delta$ ARA0.4 & $\Delta$ ARA0.8 & $\Delta$ ARA1.5 & $\Delta$ ARA3.0 \\
\hline $16: 0$ & 0.2412 & 0.13 & 5.77 & 5.33 & 5.35 & 4.44 \\
$18: 0$ & 0.7593 & 0.39 & 6.57 & 5.94 & 5.93 & 5.50 \\
$18: 1 n-9$ & 0.9775 & 0.52 & -8.41 & -8.16 & -8.06 & -7.68 \\
$18: 2 n-6$ & 0.9981 & 0.39 & -10.77 & -9.48 & -6.36 & -4.60 \\
$20: 4 n-6$ & 0.9884 & 0.53 & 2.23 & 1.21 & 0.16 & -4.48 \\
$18: 3 n-3$ & 0.9984 & 0.16 & -6.27 & -5.36 & -5.22 & -0.52 \\
$20: 5 n-3$ & 0.9965 & 2.04 & -5.26 & -5.49 & -5.97 & -6.45 \\
$22: 6 n-3$ & 0.0412 & 0.10 & 13.95 & 12.00 & 12.55 & 12.41 \\
\hline
\end{tabular}

* Negative values indicate lower fatty acid percentage in larval tissue total lipid than in dietary lipid (preferential metabolism), whereas positive values indicate accumulation in the larvae relative to the diet (preferential retention).

expression was up to 6-fold higher in ARA0·4-fed fish than in the other experimental groups.

\section{Discussion}

The present study clearly shows that gilthead sea-bream larvae can tolerate a wide range of dietary ARA levels, as neither growth rates nor survival presented significant differences between the experimental groups. Variation in responses obtained for other analysed parameters (eicosanoid levels and gene expression) did not appear to compromise the general growth performance of the fish for the duration of the experiment, and could be regarded as adaptive to the nutritional conditions tested. Relatively low survival was registered between 16 and $34 \mathrm{DAH}$, which may well relate to the stress of weaning (performed at an early life stage) combined with the fairly small tank volumes used in the rearing system. Still, the survivals observed are within the normal range for the species, despite higher values which have been reported when microdiets were offered at a later stage ${ }^{(43,55)}$. Relative growth rates may have reflected the same type of constraints, as higher values have been reported for sea-bream larvae fed caseinbased microencapsulated diets ${ }^{(56)}$. Nonetheless, sea-bream larvae more than doubled their initial weight during the experimental period and their fatty acid profiles clearly reflected the dietary fatty acid composition at the end of the study.

Besides the increase in ARA content in larval tissues from the ARA0.4 to ARA3.0 groups, it is also important to note reduced LA and LNA deposition which mirrored dietary profiles. In contrast, EPA content in ARA3.0-fed fish was about $60 \%$ that determined for ARA0.4 larvae, despite similar dietary supply levels. This reduction in EPA concomitant with increased ARA levels in larval tissues is a clear indication of competition between these fatty acids for inclusion into fish tissues by acyltransferases as reported in this ${ }^{(14)}$ and other species $^{(57)}$. The suggested displacement of EPA by increasing ARA competition is in accordance with results obtained from comparisons between dietary and larval fatty acid profiles (\% total fatty acids, see Table 6), which indicated preferential EPA metabolism, especially with the increase in dietary ARA. In fact, whereas the EPA:ARA ratio was below 1.0 only in the ARA3.0 diet, in larval whole body, the same ratio was found to be equal to or lower than 1.0 in all groups receiving dietary ARA levels above $0 \cdot 4 \%$. The EPA:ARA ratio is of particular interest since it is a major determinant of eicosanoid production and bioactivity.

An important shift in eicosanoid profiles can affect various metabolic pathways, including the stress response, as often proposed in fish ${ }^{(13,14,21,58)}$. $\mathrm{LTB}_{4}$, an eicosanoid known for its pro-inflammatory properties ${ }^{(23)}$, showed a clear increase in groups supplied with the highest dietary ARA levels. On the other hand, only such a trend could be identified regarding $\mathrm{PGE}_{2}$. Preferential ARA metabolism was in fact suggested by comparison between dietary and larval fatty acid profiles (\% total fatty acids). Nonetheless, genes related to eicosanoid production showed the highest expression in ARA0-4-fed fish, in particular PLA 2 . However, it is well known that PLA 2 is not strictly required for ARA release from cellular stores since other enzymes, such as acyl-CoA synthetase 4 and acyl-CoAthioesterase, may undertake this role ${ }^{(59)}$. Despite a nearly complete suppression of $\mathrm{PLA}_{2}$ gene expression and the significant down-regulation of $C O X-2$ and 5-LOX genes, high dietary ARA supply (3\%) or low EPA:ARA ratios in larval whole body $(0 \cdot 3)$ caused significantly higher $\mathrm{LTB}_{4}$ production. It is possible that reduced transcription of these genes was an adaptation, as a result of a negative feedback mechanism, to a transient increase in ARA-derived eicosanoids in groups supplied with dietary EPA:ARA ratios $<2 \cdot 5$, in order to maintain these metabolites within 'normal' physiological concentrations.

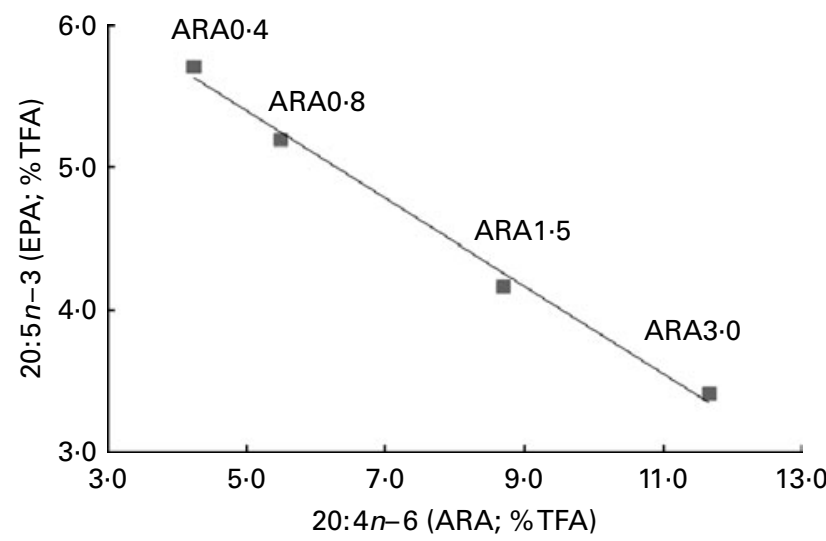

Fig. 1. Correlation between EPA and arachidonic acid (ARA) levels (\% total fatty acids (TFA)) in the whole body of sea-bream larvae fed diets containing graded ARA levels. $\mathrm{y}=-0.3074 \mathrm{x}+6.9357 ; R^{2} 0.9936$. 


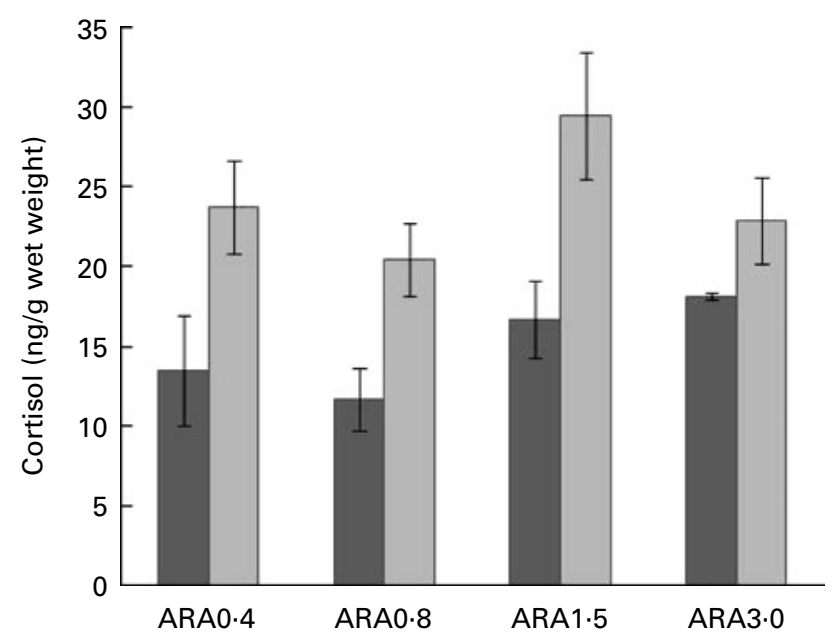

Fig. 2. Whole-body cortisol levels in sea-bream larvae fed diets containing different arachidonic acid (ARA) levels before (basal, $\square$ ) and $24 \mathrm{~h}$ ( $\square$ ) after a handling stress (1 min stirring). Values are treatment means, with standard errors represented by vertical bars. Absence of letters denotes no statistical differences between the dietary treatments within the sampling times $(P>0.05 ;$ ANOVA). A significant effect of stress was found $(P<0.05$; ANOVA).

A study in 28 DAH sea-bream larvae showed cortisol peaks about $20-40 \mathrm{~min}$ past a similar type of stress ${ }^{(14)}$. All groups seemed to be able to cope with the acute stress imposed, as survival past $24 \mathrm{~h}$ was $84-90 \%$, overall, and cortisol levels did not differ significantly between groups at this time. Together, these data suggest that larval resistance to the stress test was not affected by the diets, which further support the idea that sea-bream larvae could adapt to changes induced by different fatty acid levels. Various studies in sea-bream larvae have reported positive effects of ARA on growth, survi$\mathrm{val}^{(9)}$ or stress resistance ${ }^{(12,14)}$, although results may depend much on the nature of the stressor applied, larval stage $^{(13,14)}$, feed type, rearing conditions, genetic factors, as well as on the relative abundance of other fatty acids ( $n-3$ LC-PUFA). Hence, a direct comparison between studies conducted in different laboratories may be difficult. For instance, an effect of EPA supply has been reported previously in seabream larvae survival to air exposure and temperature shock $^{(60)}$, whereas the present results showed no trend in stress resistance despite the reduction in larval EPA as ARA increased. However, the maintenance of elevated DHA levels in all groups (27-29\% total fatty acids) compared with previously cited studies could have masked effects potentially induced by ARA or other fatty acids on stress resistance. Studies in the larvae of other marine fish species also support the superior role of DHA as an essential fatty acid relative to EPA and ARA in terms of growth and resistance to a vitality test $^{(61,62)}$. In the face of a stressor, efficient ATP production is required to satisfy the extra energy demand. It is possible that larval cardiorespiratory performance, for example, could be affected by dietary DHA which is structurally important for cardiolipin, a phospholipid found abundantly in fish mitochondrial membranes ${ }^{(20)}$.

The present experiment evidenced effects of fatty acid supply on the modulation of the expression of various genes in undisturbed sea-bream larvae. The ability of metabolic factors to activate PPAR allows for these transcription factors to alter gene expression in response to the nutritional status of the animal $^{(63)}$. $\mathrm{LTB}_{4}$ and ARA, but also $\mathrm{C}_{18}$ unsaturates, are important ligands for PPAR $\alpha^{(64)}$, and therefore may have affected its transcriptional activity. This could potentially involve the regulation of the StAR gene ${ }^{(33)}$ and, in fact, the expression pattern of the two genes among the experimental groups presented striking similarities. The implications of LC-PUFA and their derivatives in steroidogenesis, particularly cortisol synthesis, are numerous and complex, and have been addressed in recent years in sea-bream studies ${ }^{(24,25)}$. Still, differences in StAR expression among the groups did not affect basal cortisol levels. In fact, the control of StAR activity even following acute stress or ACTH signalling in fish may be exerted at the posttranscriptional level ${ }^{(65-67)}$, involving steps such as StAR protein phosphorylation for the activation of the enzyme ${ }^{(68)}$.

GR are central in mediating the genomic actions of cortisol and the present study clearly demonstrated a down-regulation of the GR gene expression with increasing dietary ARA supply. Various GR transcription factors, which are sensitive to fatty acid signalling, may mediate this effect. In mammals, NF- $\mathrm{B}$ and activator protein 1 , for example, can be directly activated by fatty acids such as LA and EPA, or by PPAR to regulate GR transcription ${ }^{(69-71)}$. As previously noted, differences in larval fatty acid profiles were not limited to ARA, and it is likely that gene expression results reflected the combined actions
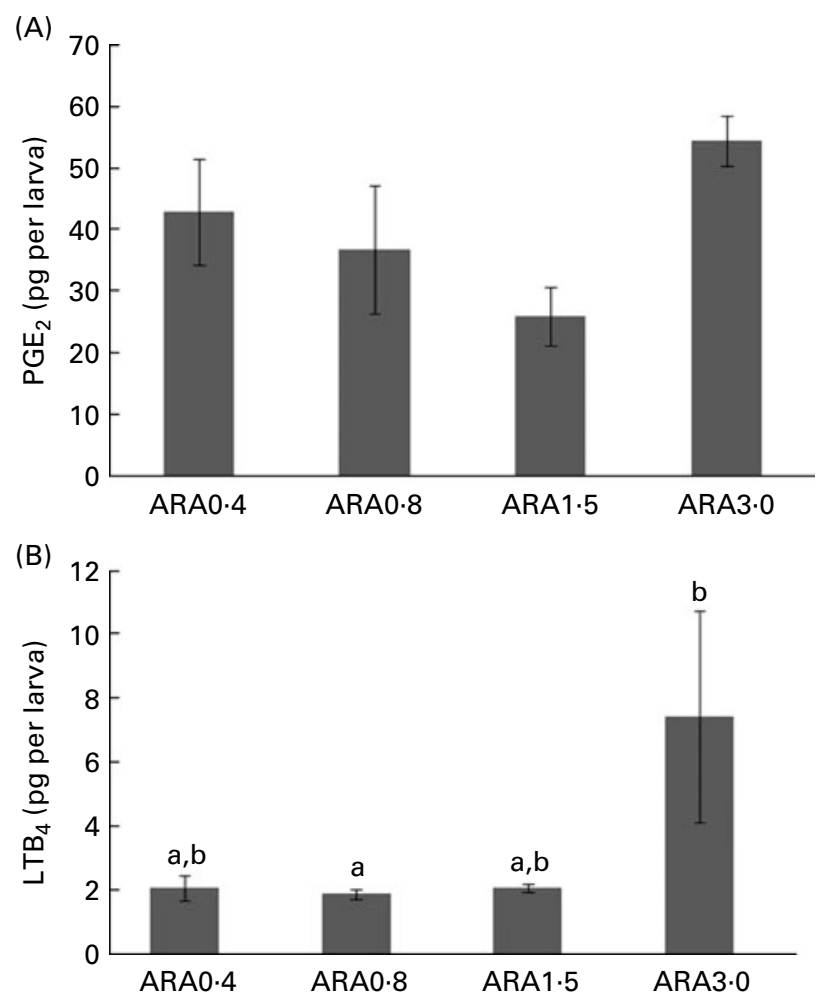

Fig. 3. Whole-body $(A) P G E_{2}$ and $(B)$ leukotriene $B_{4}\left(L T B_{4}\right)$ concentrations in sea-bream larvae fed diets containing different arachidonic acid (ARA) levels. Values are treatment means, with standard errors represented by vertical bars. ${ }^{a, b}$ Mean values with unlike letters were statistically different between the treatments $(P<0.05$; ANOVA $)$. 

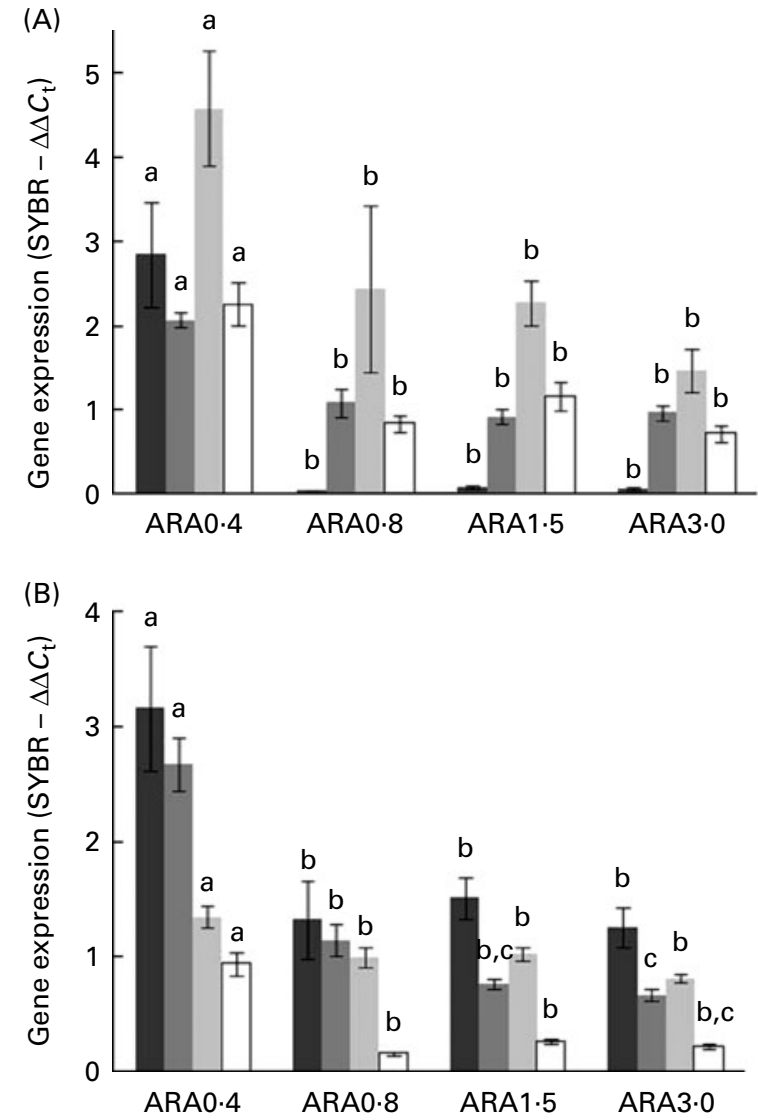

Fig. 4. Whole-body expression of genes in sea-bream larvae fed diets containing different ARA levels. (A) Results relative to phospholipase $A_{2}(\square)$, 5-lipoxygenase $(\square)$, cyclo-oxygenase-2 ( $\square$ ) and PPAR $\alpha(\square)$. (B) Results relative to steroidogenic acute regulatory protein $(\square)$, glucocorticoid receptor $(\square)$, hormone-sensitive lipase ( $\square$ ) and phosphoenolpyruvate carboxykinase (口). Values are treatment means, with standard errors represented by vertical bars. ${ }^{a, b, c}$ Mean values with unlike letters were statistically different between the treatments $(P<0.05$; ANOVA).

of other fatty acids (EPA, LA and LNA). In sea-bream larvae fed similar microdiets varying in lecithin source, up-regulation of the GR gene in soyabean lecithin-fed fish was associated with higher LA and slightly reduced ARA levels in the larval polar and total lipids ${ }^{(43)}$. In comparison, the present results showed higher variation in the expression of the GR gene, which could be due to larger discrepancies between LA and ARA contents between the groups. Therefore, clear evidence exists that GR gene expression in sea bream can be affected by dietary LA and/or ARA supply.

Slightly increased HSL expression associated with higher GR expression was found in the ARA0-4-fed groups relative to the other treatments, as reported previously ${ }^{(43)}$. In addition, highest PEPCK transcript levels were found in these fish. The two genes are known to respond to GR activity in mammals, although, to our knowledge, a corticosteroid-responsive element has not been identified in fish HSL promoter ${ }^{(48,49)}$. Both enzymes are responsible for the release of energy substrates into the blood stream. Given the differences in expression between the groups under basal conditions, particularly of the PEPCK gene, it would be interesting to assess their expression in response to an acute stress.
In summary, the present study demonstrated that gilthead sea-bream larvae adaptation to a wide range of dietary ARA levels involves changes in the expression of genes associated with eicosanoid synthesis, lipid metabolism and stress response. All genes analysed were significantly downregulated in sea-bream larvae presenting whole-body EPA:ARA ratios $<1$, but also lower LA and LNA levels relative to the ARA0 4 groups. Therefore, observed effects may not be due to the increase in ARA supply alone. Fatty acids and their derivatives can signal nuclear receptors and transcription factors (such as PPAR), interact with StAR and GR, indirectly modulate metabolic pathways related to energetic metabolism (HSL and PEPCK), and ultimately affect stress-coping ability. It is possible that high larval DHA levels in all experimental groups contributed to the absence of differences in growth and survival after an acute stress challenge, masking potential effects of deficient/excessive ARA supply or of an inadequate dietary ARA:EPA ratio. Considering the increasing interest in promoting animal welfare under intensive farming conditions, and within the current context of research for alternative dietary lipid sources in aquaculture, this information may be valuable for the optimisation of feeds containing vegetable oils rich in C18 fatty acids but lacking in LC-PUFA.

\section{Acknowledgements}

The authors wish to acknowledge Dr Luísa Valente (Centro Interdisciplinar de Investigação Marinha e Ambiental, Portugal) for kindly assisting in dietary composition analysis. This study was supported by 'Fundação para a Ciência e a Tecnologia', (FCT, Portugal; EFARFish - 'A new method for the study of essential fatty acid requirements in fish larvae' PTDC/MAR/67017/2006); 'Consolider - Ingenio 2010' programme (Plan Nacional I + D + I + FEDER, Spain; 'Aquagenomics - Improvement of aquaculture production by the use of biotechnological tools' CSD2007-00002); MCYT + FEDER (Plan Nacional I + D + I, Spain; 'Mejora del aprovechamiento del alimento en primeras edades de peces marinos: funcionalidad del tubo digestivo y valoración de la utilización de macronutrientes' AGL2007-64450-C02-01); POCTEP Programme (0251-ECOAQUA-5-E). D. A. M. was supported by grant SFRH/BPD/32469/2006 (FCT, Portugal). The study also benefited from the LARVANET grants COST-STSM-FA08014496 and COST-STSM-FA0801-5429. The authors disclose no conflicts of interest. The authors' contributions were as follows: D. A. M., S. M., M. Y. and L. E. C. C. designed the study; D. A. M. and M. Y. formulated and manufactured the diets; F. R. analysed the diets; F. R., F. C., D. A. M. and L. E. C. C. conducted the experiment; D. A. M. and F. C. conducted cortisol analysis; F. R. and G. M.-R. were responsible for gene expression analyses; D. A. M. and G. B. conducted eicosanoid determinations; F. R., N. B. and J. C. were involved in lipid and fatty acid composition analyses; D. A. M. and F. R. performed the statistical analysis; all authors contributed to manuscript writing, and D. A. M. had primary responsibility for the final content. All authors read and approved the manuscript. 


\section{References}

1. Conte FS (2004) Stress and the welfare of cultured fish. Appl Anim Behav Sci 86, 205-223.

2. Barton BA (2002) Stress in fishes: a diversity of responses with particular reference to changes in circulating corticosteroids. Integr Comp Biol 42, 517-525.

3. Portz DE, Woodley CM \& Cech JJ (2006) Stress-associated impacts of short-term holding on fishes. Rev Fish Biol Fisher 16, 125-170.

4. Fletcher TC (1997) Dietary effects on stress and health. In Fish Stress and Health in Aquaculture, pp. 223-246 [GK Iwama, AD Pickering, JP Sumpter and CB Schreck, editors]. Cambridge: Cambridge University Press

5. Weirich CR \& Reigh RC (2001) Dietary Lipids and Stress Tolerance of Larval Fish. Binghamton, NY: Food Products Press.

6. Montero D, Kalinowski T, Obach A, et al. (2003) Vegetable lipid sources for gilthead seabream (Sparus aurata): effects on fish health. Aquaculture 225, 353-370.

7. Sargent J, McEvoy L, Estévez A, et al. (1999) Lipid nutrition of marine fish during early development: current status and future directions. Aquaculture 179, 1-4.

8. Cahu CL, Gisbert E, Villeneuve LAN, et al. (2009) Influence of dietary phospholipids on early ontogenesis of fish. Aquac Res 40, 989-999.

9. Bessonart M, Izquierdo MS, Salhi M, et al. (1999) Effect of dietary arachidonic acid levels on growth and survival of gilthead sea bream (Sparus aurata L.) larvae. Aquaculture 179, $1-4$.

10. Bell JG \& Sargent JR (2003) Arachidonic acid in aquaculture feeds: current status and future opportunities. Aquaculture 218, 491-499.

11. Koven W (2002) Gilthead sea bream, Sparus aurata. In Nutrient Requirements and Feeding of Finfish for Aquaculture, pp. 64-78 [CD Webster and C Lim, editors]. New York, NY: CAB International Publishers.

12. Koven W, Barr Y, Lutzky S, et al. (2001) The effect of dietary arachidonic acid (20:4n-6) on growth, survival and resistance to handling stress in gilthead seabream (Sparus aurata) larvae. Aquaculture 193, 1-2.

13. Koven W, Van Anholt R, Lutzky S, et al. (2003) The effect of dietary arachidonic acid on growth, survival, and cortisol levels in different-age gilthead seabream larvae (Sparus auratus) exposed to handling or daily salinity change. Aquaculture 228, 307-320.

14. Van Anholt RD, Koven WM, Lutzky S, et al. (2004) Dietary supplementation with arachidonic acid alters the stress response of gilthead seabream (Sparus aurata) larvae. Aquaculture 238, 369-383.

15. Dhert P, Lavens P, Duray M, et al. (1990) Improved larval survival at metamorphosis of Asian sea bass Lates calcarifer using omega-3 hufa-enriched live food. Aquaculture 90, $63-74$.

16. Kraul S, Brittain K, Cantrell R, et al. (1993) Nutritional factors affecting stress resistance in the larval mahimahi Coryphaena hippurus. J World Aquacult Soc 24, 186-193.

17. Kanazawa A (1997) Effects of docosahexaenoic acid and phospholipids on stress tolerance of fish. Aquaculture $\mathbf{1 5 5}$, $1-4$.

18. Kanazawa A (1998) Importance of dietary lipids in flatfish. In Nutrition and Technical Development of Aquaculture, Proceedings of the Twenty-sixth US-Japan Aquaculture Symposium, Durbam, NH, 1997, pp. 181-186 [WH Howell, BJ Keller, PK Park, JP McVey, K Takayanagi and Y Uekita, editors]. United States-Japan Cooperative Program in Natural Resources Technical Report 26.
19. Liu J-K, Wang W-Q, Li K-R, et al. (2002) Effects of fish oil, DHA oil and lecithin in microparticulate diets on stress tolerance of larval gilthead seabream (Sparus aurata). Chin J Oceanol Limnol 20, 338-343.

20. McKenzie DJ (2005) Effects of dietary fatty acids on the physiology of environmental adaptation in fish. In Physiological and Ecological Adaptations to Feeding in Vertebrates, pp. 363-388 [JM Starck and T Wang, editors]. Enfield, New Hampshire: Science Publishers.

21. Wales NAM (1988) Hormone studies in Myxine glutinosa effects of the eicosanoids arachidonic-acid, prostaglandin$\mathrm{E}_{1}$, prostaglandin- $\mathrm{E}_{2}$, prostaglandin- $\mathrm{A}_{2}$, prostaglandin- $\mathrm{F}_{2}$, thromboxane $\mathrm{B}_{2}$ and of indomethacin on plasma cortisol, blood pressure, urine flow and electrolyte balance. J Comp Physiol B 158, 621-626.

22. Tocher DR (2003) Metabolism and functions of lipids and fatty acids in teleost fish. Rev Fish Sci 11, 107-184.

23. Calder PC (2009) Polyunsaturated fatty acids and inflammatory processes: new twists in an old tale. Biochimie $\mathbf{9 1}$ 791-795.

24. Ganga R, Tort L, Acerete L, et al. (2006) Modulation of ACTH-induced cortisol release by polyunsaturated fatty acids in interrenal cells from gilthead seabream. Sparus aurata. J Endocrinol 190, 39-45.

25. Ganga R, Bell JG, Montero D, et al. (2011) Adrenocorticotrophic hormone-stimulated cortisol release by the head kidney inter-renal tissue from sea bream (Sparus aurata) fed with linseed oil and soyabean oil. Brit J Nutr 105, $238-247$

26. Stocco DM, Wang XJ, Jo Y, et al. (2005) Multiple signalling pathways regulating steroidogenesis and steroidogenic acute regulatory protein expression: more complicated than we thought. Mol Endocrinol 19, 2647-2659.

27. Wang XJ, Dyson MT, Jo Y, et al. (2003) Involvement of 5-lipoxygenase metabolites of arachidonic acid in cyclic AMP-stimulated steroidogenesis and steroidogenic acute regulatory protein gene expression. J Steroid Biochem $\mathbf{8 5}$, $159-166$

28. Wang XJ, Dyson MT, Jo Y, et al. (2003) Inhibition of cyclooxygenase-2 activity enhances steroidogenesis and steroidogenic acute regulatory gene expression in MA-10 mouse Leydig cells. Endocrinology 144, 3368-3375.

29. Wang XJ, Shen CL, Dyson MT, et al. (2006) The involvement of epoxygenase metabolites of arachidonic acid in cAMPstimulated steroidogenesis and steroidogenic acute regulatory protein gene expression. J Endocrinol 190, 871-878.

30. Desvergne B \& Wahli W (1999) Peroxisome proliferatoractivated receptors: nuclear control of metabolism. Endocr Rev 20, 649-688.

31. Zhang Y \& Mangelsdorf DJ (2002) LuXuRies of Lipid homeostasis: the unity of nuclear hormone receptors, transcription regulation, and cholesterol sensing. Mol Interv 2, 78-87.

32. Xie YI, Yang Q \& DePierre JW (2002) The effects of peroxisome proliferators on global lipid homeostasis and the possible significance of these effects to other responses to these xenobiotics: an hypothesis. Ann NY Acad Sci 973, 17-25.

33. Kowalewski MP, Dyson MT, Manna PR, et al. (2009) Involvement of peroxisome proliferator-activated receptor gamma in gonadal steroidogenesis and steroidogenic acute regulatory protein expression. Reprod Fert Develop 21, 909-922.

34. Borch J, Metzdorff SB, Vinggaard AM, et al. (2006) Mechanisms underlying the anti-androgenic effects of diethylhexyl phthalate in fetal rat testis. Toxicology 233, 144-155.

35. Pavlikova N, Kortner TM \& Arukwe A (2010) Modulation of acute steroidogenesis, peroxisome proliferator-activated receptors and CYP3A/PXR in salmon interrenal tissues by 
tributyltin and the second messenger activator, forskolin. Chem-Biol Interact 185, 119-127.

36. Striggow F \& Ehrlich BE (1997) Regulation of intracellular calcium release channel function by arachidonic acid and leukotriene $\mathrm{B}_{4}$. Biochem Biophys Res Commun 237, 413-418.

37. Shuttleworth TJ, Thompson JL \& Mignen O (2004) ARC channels: a novel pathway for receptor-activated calcium entry. Physiology 19, 355-361.

38. Holmes AM, Roderick HL, McDonald F, et al. (2007) Interaction between store-operated and arachidonate-activated calcium entry. Cell Calcium 41, 1-12.

39. Meves $H$ (2008) Arachidonic acid and ion channels: an update. Br J Pharmacol 155, 4-16.

40. Prunet P, Sturm A \& Milla S (2006) Multiple corticosteroid receptors in fish: From old ideas to new concepts. Gen Comp Endocrinol 147, 17-23.

41. Pottinger TG \& Brierley I (1997) A putative cortisol receptor in the rainbow trout erythrocyte: stress prevents starvationinduced increases in specific binding of cortisol. $J$ Exp Biol 200, 2035-2043.

42. Borski RJ (2000) Nongenomic membrane actions of glucocorticoids in vertebrates. Trends Endocrinol Metab 11, 427-436.

43. Alves Martins D, Estévez A, Stickland NC, et al. (2010) Dietary lecithin source affects growth potential and gene expression in Sparus aurata larvae. Lipids 45, 1011-1023.

44. Lee PC \& Struve M (1992) Unsaturated fatty-acids inhibit glucocorticoid receptor-binding of trout hepatic cytosol. Comp Biochem Phys B 102, 707-711.

45. Junzo K, Akiko T, Naoki M, et al. (1987) Modulation of brain progestin and glucocorticoid receptors by unsaturated fatty acid and phospholipid. J Steroid Biochem 27, 641-648.

46. Viscardi RM \& Max SR (1993) Unsaturated fatty acid modulation of glucocorticoid receptor binding in L2 cells. Steroids $\mathbf{5 8}, 357-361$.

47. Hedman E, Widen C, Asadi A, et al. (2006) Proteomic identification of glucocorticoid receptor interacting proteins. Proteomics 6, 3114-3126.

48. Le PP, Friedman JR, Schug J, et al. (2005) Glucocorticoid receptor-dependent gene regulatory networks. PLoS Genet 1, 159-170.

49. Lampidonis AD, Stravopodis DJ, Voutsinas GE, et al. (2008) Cloning and functional characterization of the $5^{\prime}$ regulatory region of ovine Hormone Sensitive Lipase (HSL) gene. Gene 427, 65-79.

50. Yúfera M, Fernández-Díaz C \& Pascual E (2005) Food microparticles for larval fish prepared by internal gelation. Aquaculture 248, 253-262.

51. Cohen Z, Vonshak A \& Richmond A (1988) Effect of environmental conditions on fatty acid composition of the red alga Porphyridium cruentum: correlation to growth rate. J Phycol 24, 328-332.

52. Bell JG, Tocher DR, MacDonald FM, et al. (1994) Effects of diets rich in linoleic (18:2n-6) and alpha-linolenic (18:3n-3) acids on the growth, lipid class and fatty acid compositions and eicosanoid production in juvenile turbot (Scophthalmus maximus L.). Fish Physiol Biochem 13, 105-118.

53. Livak KJ \& Schmittgen TD (2001) Analysis of relative gene expression data using real-time quantitative PCR and the 2[Delta][Delta]CT method. Methods 25, 402-408.

54. Ricker WE (1958) Handbook of computations for biological statistics of fish populations. Can J Fish Aquat Sci 119 , $1-300$.
55. Aragão C, Conceição LEC, Lacuisse M, et al. (2007) Do dietary amino acid profiles affect performance of larval gilthead seabream? Aquat Living Resour 20, 155-161.

56. Yúfera M, Fernández-Díaz C, Pascual E, et al. (2000) Towards an inert diet for first-feeding gilthead seabream Sparus aurata L. larvae. Aquacult Nutr 6, 143-152.

57. Sargent J, Bell G, McEvoy L, et al. (1999) Recent developments in the essential fatty acid nutrition of fish. Aquaculture 177, 191-199.

58. Ganga R, Bell JG, Montero D, et al. (2005) Effect of dietary lipids on plasma fatty acid profiles and prostaglandin and leptin production in gilthead seabream (Sparus aurata). Comp Biochem Phys B 142, 410-418.

59. Maloberti P, Maciel EC, Castillo AF, et al. (2007) Enzymes involved in arachidonic acid release in adrenal and Leydig cells. Mol Cell Endocrinol 265, 113-120.

60. Liu J, Caballero MJ, Izquierdo M, et al. (2002) Necessity of dietary lecithin and eicosapentaenoic acid for growth, survival, stress resistance and lipoprotein formation in gilthead sea bream Sparus aurata. Fisheries Sci 68, 1165-1172.

61. Zheng F, Takeuchi T, Yoseda K, et al. (1996) Requirement of larval cod for arachidonic acid, eicosapentaenoic acid, and docosahexaenoic acid using by their enriched Artemia nauplii. Nippon Suisan Gakk 62, 669-676.

62. Ishizaki $\mathrm{Y}$, Takeuchi $\mathrm{T}$, Watanabe $\mathrm{T}$, et al. (1998) A preliminary experiment on the effect of artemia enriched with arachidonic acid on survival and growth of yellowtail. Fisheries Sci 64, 295-299.

63. Komar CM (2005) Peroxisome proliferator-activated receptors (PPARs) and ovarian function - implications for regulating steroidogenesis, differentiation, and tissue remodeling. Reprod Biol Endocrinol 3, 14.

64. Lin Q, Ruuska SE, Shaw NS, et al. (1999) Ligand selectivity of the peroxisome proliferator-activated receptor $\alpha$. Biochemistry 38, 185-190.

65. Geslin M \& Auperin B (2004) Relationship between changes in mRNAs of the genes encoding steroidogenic acute regulatory protein and $\mathrm{P} 450$ cholesterol side chain cleavage in head kidney and plasma levels of cortisol in response to different kinds of acute stress in the rainbow trout (Oncorbynchus mykiss). Gen Comp Endocrinol 135, 70-80.

66. Hagen IJ, Kusakabe M \& Young G (2006) Effects of ACTH and CAMP on steroidogenic acute regulatory protein and P450 11ß-hydroxylase messenger RNAs in rainbow trout interrenal cells: relationship with in vitro cortisol production. Gen Comp Endocrinol 145, 254-262.

67. Castillo J, Castellana B, Acerete L, et al. (2008) Stress-induced regulation of steroidogenic acute regulatory protein expression in head kidney of Gilthead seabream (Sparus aurata). J Endocrinol 196, 313-322.

68. Arakane F, King SR, Du Y, et al. (1997) Phosphorylation of steroidogenic acute regulatory protein (StAR) modulates its steroidogenic activity. J Biol Chem 272, 32656-32662.

69. Dichtl W, Nilsson L, Goncalves I, et al. (1999) Very lowdensity lipoprotein activates nuclear factor-kappa $\mathrm{B}$ in endothelial cells. Circ Res 84, 1085-1094.

70. Yudt MR \& Cidlowski JA (2002) The glucocorticoid receptor: coding a diversity of proteins and responses through a single gene. Mol Endocrinol 16, 1719-1726.

71. Jia Y \& Turek JJ (2005) Altered NF-kappa B gene expression and collagen formation induced by polyunsaturated fatty acids. J Nutr Biochem 16, 500-506. 